\title{
Tilikan Politik dan Hak Asasi Manusia di Era Globalisasi
}

\author{
Paulus Eko Kristianto \\ Sekolah Tinggi Filsafat Driyarkara \\ Email: paulusekokristianto@gmail.com; \\ Hengki Wijaya \\ Sekolah Tinggi Filsafat Jaffray Makassar \\ Email: hengkiwijaya@sttjaffray.ac.id
}

\begin{abstract}
AbstraK
Artikel ini mencoba menelusuri tilikan politik dan hak asasi manusia di era globalisasi. Globalisasi tidak boleh dipandang sekedar proses perdagangan bebas saja, melainkan banyak menyentuh persoalan kebudayaan. Disadari atau tidak, kebudayaan bersifat kompleks dan majemuk sehingga kita dapat meragukan apakah mereka dapat memobilisasi sebuah konflik global. Namun, kita dapat menilainya bahwa kebudayaan ternyata dapat diinstrumentalisasi secara politis dan ideologis untuk mengabsolutkan perbedaan-perbedaan. Problematika nilai tidak berhenti pada aspek kebudayaan dan kemasyarakatan, melainkan memuncak pada momen-momen politis. Hal itu dikarenakan konsepsi kenegaraan antinomi antara individualisme Barat dan kolektivisme Asia kerap ditekan-tekankan oleh para pemimpin negara-negara di Asia. Dalam kondisi ini, kita dapat melihat bagaimana hak asasi manusia bekerja. Penelusuran tilikan politik dan hak asasi manusia ini dikemas dengan menggunakan metode penelitian kajian pustaka dengan menggunakan buku dan jurnal yang relevan dengan bahasan yang ada. Hasil penelitian dan penulisan artikel ini menunjukkan bahwa dalam tilikan politik, kita tidak boleh lupa bahwa hak asasi manusia harus dipahami sebagai kebebasan untuk bertindak tanpa pembatasan. Hal ini tentu bermakna bahwa seolah-olah pelaksanaan hak-hak tersebut tidak mensyaratkan pengujian etis dan tanggung jawab sehingga dibutuhkan gagasan tentang kewajiban. Bila diteliti, pemikiran ini tentu tidak sesuai dengan apa yang menjadi intensi deklarasi hak-hak asasi manusia. Dalam hal ini, kebebasan bukanlah dipahami sebagai pemakaian kesewenangan, melainkan ditafsirkan dalam horizon keutamaan dan kesejahteraan umum.
\end{abstract}

Kata-kata Kunci: Politik, Hak Asasi Manusia, Globalisasi, Kebudayaan, Ideologi 


\section{Pendahuluan}

Samuel P. Huntington meramalkan bahwa konflik-konflik utama politik global akan berlangsung di antara bangsa-bangsa dan kelompok-kelompok dari berbagai kebudayaan. Menurutnya, sumber konflik-konflik di masa depan bukanlah ideologi dan ekonomi, melainkan kebudayaan. ${ }^{1}$ Disadari atau tidak, kebudayaan bersifat kompleks dan majemuk sehingga kita dapat meragukan apakah mereka dapat memobilisasi sebuah konflik global. Namun, kita dapat menilainya bahwa kebudayaan ternyata dapat diinstrumentalisasi secara politis dan ideologis untuk mengabsolutkan perbedaan-perbedaan. F. Budi Hardiman meneguhkan pemikiran ini dengan menunjukkan adanya upaya revitalisasi identitas etnis dan religius di berbagai negara non-Barat dan juga teror atas nama Islam yang tampil di masa sekarang. ${ }^{2}$ Mereka tampaknya memprovokasi suatu politik identitas yang menekankan kekhasan tradisi kebudayaannya.

Berpijak pada kondisi tersebut, penulis mencoba mengkaji Hak-Hak Asasi Manusia di Era Globalisasi dengan menggunakan sudut pandang etika politik. Etika politik merupakan salah catu cabang filsafat yang mempertanyakan tanggung jawab dan kewajiban manusia mengenai dimensi politis manusia. F. Magnis-Suseno memetakan dimensi politis manusia menunjuk pada manusia sebagai makhluk sosial, dimensi kesosialan, dimensi politis kehidupan manusia. ${ }^{3}$ Secara prinsip, manusia sebagai makhluk sosial dipahami bahwa manusia hanya mempunyai eksistensi karena orang lain. Segala ketrampilan yang dibutuhkannya untuk berhasil dalam kehidupan dan berpartisipasi dalam kebudayaan diperolehnya dari masyarakat. Hal ini termasuk cara manusia memandang dunia, menghayati diri sendiri, menyembah Tuhan, dan menyadari apa yang menjadi kewajibannya. Disadari atau tidak, manusia secara mendalam ditentukan oleh masyarakat. Ketergantungan dan keterlibatan individu dengan masyarakat dapat disebut kesosialan manusia yang ternyatakan dalam tiga dimensi: (1) dalam penghayatan spontan individual; (2) berhadapan dengan lembaga-lembaga; (3) melalui pengertian-pengertian simbolis terhadap realitas. ${ }^{4}$ Dalam kerangka dimensi kesosialan manusia, dimensi politis mencakup lingkaran kelembagaan hukum, negara, sistem nilai, dan ideologi yang memberikan legitimasi kepadanya. Dimensi politis manusia adalah dimensi masyarakat sebagai keseluruhan. Jadi, yang menjadi ciri khas

\footnotetext{
${ }^{1}$ Samuel P. Huntington. "The Clash of Civilization?” dalam Foreign Affairs, Musim Panas 1993, h. 22. dikutip F. Budi Hardiman. Hak-Hak Asasi Manusia, h. 87-88.

${ }^{2}$ Lihat F. Budi Hardiman. Hak-Hak Asasi Manusia: Polemik dengan Agama dan Kebudayaan. (Yogyakarta: Kanisius, 2011), h. 88.

${ }^{3}$ Franz Magnis-Suseno. Etika Politik: Prinsip Moral Dasar Kenegaraan Modern. (Jakarta: Gramedia, 2016), h. 11-20.

${ }^{4}$ Franz Magnis-Suseno. Etika Politik, h. 14.
} 
suatu pendekatan yang disebut "politis" adalah pendekatan itu terjadi dalam kerangka acuan yang berorientasi pada masyarakat sebagai keseluruhan. Dengan kata lain, dimensi politis manusia dapat ditentukan sebagai dimensi di mana manusia menyadari diri sebagai anggota masyarakat merupakan anggota keseluruhan yang menentukan kerangka kehidupannya dan ditentukan kembali oleh tindak-tanduknya. Bila ditelusuri, ketiga dimensi politis manusia bekerja secara elaboratif.

\section{Dari Pembangunan ke Globalisasi}

Disadari atau tidak, kita sedang mengalami krisis pembangunan. Kapitalisme di Asia Timur yang selama ini dijadikan teladan keberhasilan pembangunan dan keberhasilan kapitalisme dunia ketiga sedang mengalami kebangkrutan. Para pakar mulai meramalkan bahwa era ini dapat dikatakan sebagai peristiwa berakhirnya era developmentalisme di mana sebagai sebuah proses perubahan sosial pasca perang dunia kedua yang dibangun di atas landasan paham modernisasi menuju babak-babak akhir. ${ }^{5}$ Krisis terhadap pembangunan yang sedang terjadi pada dasarnya merupakan bagian dari krisis sejaran dominasi dan eksploitasi manusia atas manusia yang lain, yang diperkirakan telah berusia lebih dari dua ratus tahun. Kondisi ini tentu menjadi bagian dari fase kolonialisme. Apa maksud dari fase ini? Fase kolonialisme dapat dipahami sebagai fase perkembangan kapitalisme di Eropa yang mengharuskan ekspansi secara fisik untuk memastikan perolehan bahan baku mentah. Berakhirnya kolonialisme sebenarnya telah memasukkan dunia pada era neokolonialisme, ketika modus dominasi dan penjajahan tidak lagi berupa fisik melainkan teori dan ideologi. ${ }^{6}$ Namun pada era developmentalis, dominasi negara-negara bekas jajahan terhadap bekas koloni mereka tetap dipertahankan melalui adanya kontrol terhadap teori dan proses perubahan sosial yang ada. Kondisi ini membawa kita pada pemahaman bahwa teori pembangunan atau developmentalisme merupakan bagian dari media dominan karena teori tersebut telah direkayasa menjadi paradigma dominan untuk perubahan sosial Dunia Ketiga oleh Negara Utara. ${ }^{7}$

Pertanyaan berikutnya yaitu kapan proyek globalisasi mulai berjalan? Secara prinsip, kita perlu memahami bahwa globalisasi terjadi ketika ditetapkannya formasi sosial global baru dengan ditandai oleh diberlakukannya secara global suatu mekanisme perdagangan melalui penciptaan kebijakan perdagangan bebas setelah melalui proses yang sulit di Marrakesh, Maroko sebagaimana suatu perjanjian internasional perdagangan yang dikenal dengan

\footnotetext{
${ }^{5}$ Mansour Fakih. Runtuhnya Teori Pembangunan dan Globalisasi. (Yogyakarta: Pustaka Pelajar, 2001), h. 185. ${ }^{6}$ Mansour Fakih. Runtuhnya Teori Pembangunan dan Globalisasi, h. 186.

${ }^{7}$ Michael A. Santoro. "Post-Westphalia and Its Discontents: Business, Globalization, and Human Rights in Political and Moral Perspective” dalam Business Ethics Quarterly 20: 2 (April 2010), h. 289.
} 
General Agreement on Tariff and Trade $(G A T T) .{ }^{8}$ GATT merupakan suatu perkumpulan internasional yang mengatur perilaku perdagangan antar pemerintah. GATT juga merupakan forum negosiasi perdagangan antarpemerintah dan juga pengadilan untuk menyelesaikan jika terjadi perselisihan dagang antarbangsa. Kesepakatan itu tentu dibangun atas asumsi bahwa sistem datang yang terbuka lebih efisien dibanding sistem yang proteksionis, dan dibangun di atas keyakinan bahwa persaingan bebas akan menguntungkan bagi negara yang menerapkan prinsip-prinsip efektivitas dan efisiensi.

\section{Globalisasi, Partikularisasi, dam Pengalaman Kolonialisme}

Globalisasi tidak hanya beroperasi dalam bidang ekonomi, melainkan sebuah fenomena perubahan ruang dan waktu lewat perkembangan yang makin cepat dari komunikasi global dan lalu lintas massal. Sistem-sistem kontak internasional yang komprehensif terbentuk dan jejaring komunikasi global memberi pengaruh yang sangat kuat atas konteks-konteks kehidupan lokal dan personal. Hal ini menimbulkan kesan seolah-olah melalui globalisasi akan terbentuk sebuah sistem dunia yang berlaku secara universal, akan tetapi hal itu justru tidak terjadi.

F. Budi Hardiman memetakan setidaknya ada tiga alasan pokok mengapa gagasan mengenai sebuah sistem dunia terletak sangat jauh dari kenyataan dan mengapa terjadinya sebuah sistem universal seperti itu tidak dapat diidentikkan dengan globalisasi. ${ }^{9}$ Hal itu tertuang sebagai berikut: (1) Situasi di dalam setiap negara di dunia dalam kaitannya dengan kompleksitas internalnya seperti kelompok-kelompok etnis dan religius, berbagai macam minoritas dan orientasi-orientasi politis sudah begitu rumit, berwarna-warni, tumpeng tindih, dan fragmentaris sehingga pencarian akan sebuah totalitas bukanlah benang merah yang dapat dipercaya lagi. (2) Globalisasi mencakup berbagai proses yang sangat rumit dan tidak pernah mengarah pada saling pengertian di antara bangsa-bangsa, negara-negara, dan kebudayaan-kebudayaan, melainkan sering menggiring ke arah konflik-konflik di antara mereka. Globalisasi dipahami bukan sebuah penerimaan pasif atas unsur-unsur kebudayaan asing, melainkan sintesis antara unsur-unsur kebudayaan sendiri dan kebudayaan asing. Globalisasi memiliki ambivalensi di mana terdapat kemungkinan perjumpaan kebudayaan sekaligus benturan kebudayaan-kebudayaan. (3) Bagaimanapun, pengalaman negatif selama kolonialisme tidak dapat dilupakan begitu saja dan masih mengendap dalam memori kolektif kebudayaan-kebudayaan yang dulu dijajah oleh Barat. Kolonialisme dipandang merusak

\footnotetext{
${ }^{8}$ Mansour Fakih. Runtuhnya Teori Pembangunan dan Globalisasi, h. 188.

${ }^{9}$ F. Budi Hardiman. Hak-Hak Asasi Manusia, h. 90-92.
} 
berbagai tradisi pribumi dan pranata sosial yang ada dan berefek sampai sekarang dalam berbagai ketertinggalan struktural jangka panjang.

Globalisasi terukur dari berbagai sistem-sistem nilai yang lahir di Barat, sedangkan partikularisasi dipahami sebagai perlawanan terhadap hegemoni kebudayaan Barat. Nilainilai Barat yang mengklaim diri sebagai universal dapat dikatakan berpijak pada tuntutan dasar Revolusi Amerika dan Perancis yang terangkum dalam hak-hak asasi manusia. ${ }^{10}$ Nilai ini rupanya disahkan oleh banyak negara sebagai Piagam PBB tahun 1948, sedangkan di negara-negara Asia Timur, hak-hak asasi manusia tersebut dicantumkan di konstitusi masing-masing negara sebagai hak-hak dasar. ${ }^{11}$ Dalam praktiknya, hak-hak asasi manusia yang dituntutkan oleh negara-negara Barat kepada negara-negara lain dipandang asing. Berbagai perlawanan terhadap hegemoni kebudayaan Barat yang dilakukan di Asia tidak bersumber dari berbagai perbedaan kultural, melainkan dari pengalaman kolonialisasi yang dialami oleh bangsa-bangsa di Asia. ${ }^{12}$ Para penyokong nilai-nilai Asia mencoba melindungi diri mereka dari intervensi asing terhadap urusan internal mereka dengan cara menunjukkan keberlainan kebudayaan mereka sendiri.

\section{Perdebatan-Perdebatan Seputar Nilai-Nilai Asia}

Konsep "Asia" tidak mengacu pada ketunggalan kultural. Konsep ini menyederhanakan kenyataan yang sangat majemuk dan kompleks yakni meringkas bagian bumi yang paling beragam secara geografis, kultural, religius, linguistis, dan politis. Di Asia, kita menemukan berbagai bentuk pemerintahan (demokrasi, otokrasi, negara polisi) dan berbagai macam tradisi kultural (kebudayaan, Konfusian, Islam, Buddhis). Dengan kata lain, Asia lebih merupakan produk konstruksi intelektual daripada kenyataan empiris. Di sisi lain, ketika kita berbicara tentang nilai, nilai dimengerti sebagai sebuah tolok ukur yang kepadanya manusia mengorientasikan diri dalam bertindak dan dalam cara bertindak. ${ }^{13}$ Yang dianggap nilai-nilai Asia yaitu mengutamakan kepentingan-kepentingan komunitas di atas hak-hak dan kebebasan-kebebasan individu; bersikap konsensual, paternalistis, dan kekeluargaan; hormat dan patuh kepada otoritas dan berpikir dengan berorientasi pada tatanan sosial; menguatamakan hubungan-hubungan personal; lebih memilih harmoni daripada kompetisi atau konfrontasi; mengambil keputusan dengan pola hirarkis dan vertikal; belajar dengan

\footnotetext{
${ }^{10}$ Indra de Soysa dan Krishna Chaitanya Vadlamannati. "Does Being Bound Together Suffocate or Liberate? The Effect of Economic, Social, and Political Globalization on Human Rights, 1981-2005" dalam Kyklos Vol. 64 Februari 2011 No. 1, h. 36.

${ }^{11}$ F. Budi Hardiman. Hak-Hak Asasi Manusia, h. 92.

${ }^{12}$ F. Budi Hardiman. Hak-Hak Asasi Manusia, h. 93.

${ }^{13}$ F. Budi Hardiman. Hak-Hak Asasi Manusia, h. 93.
} 
meniru dan mengasuh dengan hukuman; mengutamakan etika dan moral di atas hukum; memiliki keutamaan-keutamaan sosial di antaranya kerajinan, kerja keras, disiplin diri, dan kepatuhan. $^{14}$

Nilai Asia kerap dianggap sebagai nilai-nilai kontra. Hal itu dikarenakan untuk melindungi diri dari efek-efek kebudayaan Barat yang dianggap negatif contohnya dari individualisme yang semakin menjadi-jadi, kehancuran keluarga, dan kecenderungankecenderungan anarkis dalam negara-negara Barat yang liberal. Menurut Lee Kuan Yeuw, Barat semakin terancam bahaya dekadensi maka nilai-nilai yang lahir di Barat tidaklah dapat dijadikan contoh. ${ }^{15}$ Sikap ambivalensi Barat di dalam politik global dikritik oleh para pembela nilai-nilai Asia sebagai moral ganda. Barat memang terlihat menyuarakan kemanusiaan dan kesamaan, tetapi hal ini tidak sepenuhnya diperhatikan dalam politik global karena kepentingan-kepentingan Barat yang sesungguhnya ialah ekonomi.

Para komunitaris contohnya Michael Sandel, Charles Taylor, dan Alasdair McIntyre mengkritik gambaran manusia individualis yang ada dalam liberalisme dan menuntut prioritas nilai-nilai komuniter di atas kebebasan-kebebasan subyektif. McIntyre membayangkan negara sebagai sebuah keluarga besar yang di dalamnya para warga terikat satu sama lain dengan keutamaan-keutamaan dan keutamaan sentralnya adalah patriotisme. ${ }^{16}$ Pada sebuah model negara yang menyerupai keluarga dan prioritas kehidupan komunitas di atas individu, tekanan pada tradisi pribumi atau identitas kultural sendiri dan pentingnya rasa kekitaan dapat dikatakan sebagai argumen-argumen khas komunitarisme. Argumen-argumen para komunitaris dimungkinkan disambut baik di Asia, sekalipun orangorang Asia tidak memakai istilah komunitarianisme. Namun, para komunitaris di Asia Timur berbeda dari para komunitaris Amerika. Para komunitaris Asia Timur berkenaan para pragmatikus politis dengan argumen-argumen yang erat terkait dengan berbagai kepentingan politis mereka, sedangkan para komunitaris Amerika bergerak di dalam medan teori masyarakat.

\section{Perlawanan terhadap Demokrasi Barat dan HaK-Hak Asasi Manusia}

Problematika nilai tidak berhenti pada aspek kebudayaan dan kemasyarakatan, melainkan memuncak pada momen-momen politis. ${ }^{17} \mathrm{Hal}$ itu dikarenakan konsepsi kenegaraan antinomi antara individualisme Barat dan kolektivisme Asia kerap ditekan-tekankan oleh

\footnotetext{
${ }^{14}$ F. Budi Hardiman. Hak-Hak Asasi Manusia, h. 94.

${ }^{15}$ F. Budi Hardiman. Hak-Hak Asasi Manusia, h. 95.

${ }^{16}$ F. Budi Hardiman. Hak-Hak Asasi Manusia, h. 96.

17 Tony Evans. The Politics of Human Rights: A Global Perspective. (London: Pluto Press, 2001), h. 65.
} 
para pemimpin negara-negara di Asia. Mereka juga menolak setiap bentuk intervensi asing ke dalam urusan-urusan internal negara mereka atas nama hak-hak asasi manusia. Sikap Barat dalam hak-hak asasi manusia dilihat sebagai suatu upaya untuk membatasi pertumbuhan ekonomi dan peranan politis Asia di politik global. Karena itu, beberapa pemerintah di Asia Timur cenderung menegas-negaskan bahwa Asia memiliki pemahamannya yang khas tentang hak-hak asasi manusia dan demokrasi yang bersesuaian dengan nilai-nilai Asia dan berbagai taraf perkembangan dan tradisi menuntut konsep tersendiri tentang hak-hak asasi manusia dan demokrasi. ${ }^{18}$

Budi Hardiman memetakan empat kecenderungan perlawanan terhadap demokrasi dan hak-hak asasi manusia sebagai berikut ${ }^{19}$ (1) Pertumbuhan ekonomi memperoleh prioritas atas demokrasi dan hak-hak asasi manusia. Budi Hardiman menunjukkannya melalui pemikiran Lee Kuan Yeuw dan Suharto. Lee Kuan Yeuw berpendapat bahwa pembangunan lebih membutuhkan disiplin dan pemerintahan yang bersih daripada demokrasi, dan ia berpijak dari asumsi bahwa demokrasi dapat dihasilkan sebagai akibat dari pertumbuhan ekonomi yang juga tidak perlu mengikuti model Barat, sedangkan Suharto mengajak warga lebih mengutamakan kewajiban sosial, bakti kepada bangsa dan negara yang lebih menyatakan bahwa tujuan pembangunan nasional itu lebih penting dan mendesak daripada hak-hak asasi manusia. (2) Demokrasi Barat dan hak-hak asasi manusia dipandang tidak cocok dengan Asia, khususnya politik dan masyarakat Asia. Hal itu dikarenakan Asia memiliki gambaran-gambarannya sendiri tentang negara yang mengutamakan loyalitas dan memperhatikan otoritas serta hierarki kekuasaan yang cocok untuk konteks Asia. (3) Standar-standar hak-hak asasi manusia yang ditetapkan oleh PBB seharusnya diganti dengan berbagai konsep pribumi tentang hak-hak asasi manusia. Pemahaman ini menekankan negara sebagai subyek hukum, prinsip non-intervensi dan berbagai kewajiban individu terhadap masyarakat. (4) Media-media Barat berlaku tidak adil kepada masyarakat Asia Timur dengan cara memberi cap tirans dan diktatoris kepada semua negara yang memiliki pandangan mereka sendiri. ${ }^{20}$ Budi Hardiman menegaskan pemetaan tersebut tentu saja tidak dapat digeneralisasikan untuk seluruh Asia karena beberapa negara di Asia Timur yang membiarkan berkembangnya ruang-ruang kebebasan untuk para warga mereka memandang demokrasi dan hak-hak asasi manusia tidak hanya penting untuk kemajuan ekonomi mereka, melainkan stabilitas politis itu sendiri. ${ }^{21}$

\footnotetext{
${ }^{18}$ F. Budi Hardiman. Hak-Hak Asasi Manusia, h. 98.

${ }^{19}$ F. Budi Hardiman. Hak-Hak Asasi Manusia, h. 98-99.

${ }^{20}$ F. Budi Hardiman. Hak-Hak Asasi Manusia, h. 99.

${ }^{21}$ F. Budi Hardiman. Hak-Hak Asasi Manusia, h. 99.
} 
Persoalannya adalah sejauh mana klaim keberlainan kebudayaan Asia itu dapat dibenarkan? Budi Hardiman menegaskan tentu tidaklah mudah menilai sebuah perdebatan mengenai nilai-nilai karena kebudayaan mengandung ambivalensi dan nilai-nilai memiliki banyak wajah. Di dalam perdebatan-perdebatan itu, nilai-nilai kultural dan kepentingankepentingan politis saling tumpang tindih. Antinomi antara nilai-nilai Barat dan Asia tidak hanya superfisial, melainkan juga berbahaya. Bahaya konsep umum tersebut adalah konsepkonsep umum itu mudah disalahgunakan sebagai instrumen politis, entah sebagai tujuantujuan pembangunan, modernisasi ekonomi atau sebagai penguatan perasaan kebersamaan regional sehingga kebutuhan-kebutuhan dan kepentingan-kepentingan para individu, kelompok-kelompok, dan minoritas-minoritas ditelantarkan atau ditindas. ${ }^{22}$ Di samping itu, dalam perdebatan-perdebatan pernyataan-pernyataan faktual dan normatif seringkali saling tumpang tindih sehingga sulit dibedakan antara kenyataan dan cita-cita.

Para elit politis di Asia Timur membela nilai-nilai Asia terutama dalam rangka pertahanan terhadap intervensi Barat atas nama hak-hak asasi manusia. ${ }^{23}$ Kita tidak dapat membantah bahwa nilai-nilai kultural yang dalam perdebatan-perdebatan itu dianggap khas Asia itu ada dalam kehidupan kultural bangsa-bangsa di Asia Timur. Nilai-nilai itu berfungsi sebagai kerangka yang menopang makna yang dengannya orang-orang Asia dapat mengembangkan keyakinan-keyakinan, solidaritas-solidaritas, dan identitas mereka. Cara hidup orang Asia, di antaranya Indonesia, China, Singapura, dalam kasus-kasus konflik mengutamakan tatanan hirarkis, musyawarah, otoritas, dan komunitas dan berupaya sedapat mungkin untuk menghindari konflik-konflik, penegasan diri individual, konfrontasi dengan atasan atau dengan para senior. Keutamaan-keutamaan orang Asia dapat berkembang dalam medium nilai-nilai tersebut.

Pertanyaan reflektif yang dapat kita renungkan yaitu apakah Asia seperti yang dahulu kita miliki dan masih ingin kita miliki sekarang, masih ada? Kalau Asia-nya sudah berubah, dan memang kita sendiri yang menginginkan perubahan itu, bagaimana kita harus bisa berbicara dan mempertahankan nilai-nilai Asia tersebut? ${ }^{24}$ Bila ditelusuri, para elite politis Asia Timur menggunakan pemahaman diri kultural ini untuk menangkal serangan-serangan dari luar yang memberi nada yang berbeda kepada pernyataan-pernyataan mereka tentang kekhasan nilai-nilai negara mereka. Pernyataan-pernyataan itu tidak hanya diarahkan untuk melawan tekanan dari Barat semacam ideologi penangkal, melainkan juga melawan setiap desakan di

\footnotetext{
${ }^{22}$ F. Budi Hardiman. Hak-Hak Asasi Manusia, h. 100.

${ }^{23}$ Alison Brysk dan Gershon Shafir (ed.). People Out of Place: Globalization, Human Rights, and Citizenship Gap. (New York \& London: Routledge, 2004), h. 76.

${ }^{24}$ F. Budi Hardiman. Hak-Hak Asasi Manusia, h. 102.
} 
dalam negeri dari suara-suara yang kritis dan oposisional yaitu menadi semacam kepentingan legitimasi para penguasa.

\section{Tilikan Politik dan Hak Asasi Manusia}

Sejak zaman penjajahan Eropa dan Amerika Serikat memiliki hegemoni di dunia, suatu posisi kekuasaan Mondial seperti itu memungkinkan mereka untuk mengklaim diri mereka sebagai pemberi arah dalam politik global dan menjadi kebal terhadap kritik-kritik yang dilontarkan dari negara-negara non-Barat. ${ }^{25}$ Wolf Lepenies menyebut masyarakat Barat sebagai kebudayaan-kebudayaan pengajaran. ${ }^{26}$ Sebutan ini membuat Barat cenderung mengkritik kebudayaan lain secara arogan dan narsistis. Jika kita memahami kebudayaan sebagai respon khas suatu bangsa atas tantangan lingkungannya sendiri, berbagai kebudayaan di dunia tentu harus dianggap setara dan ekuiprimordial. Memang tidak dipungkiri, ada kebudayaan-kebudayaan yang lebih rumit daripada yang lain dan memiliki pranata-pranata yang lebih kompleks, namun hal itu tidak berarti bahwa kebudayaankebudayaan yang lebih rumit itu lebih rumit itu lebih tinggi tingkatnya daripada yang lain.

Di zaman pasca-kolonial, orang tidak lagi berbicara mengenai beban orang kulit putih yaitu semacam kesadaran atau rasa tanggung jawab dari orang Barat untuk memberadabkan orang-orang di seberang lautan, akan tetapi tetap ada bahaya bahwa hal itu digantikan dengan kecenderungan Barat untuk mengajari kebudayaan-kebudayaan lain untuk mengikuti kriteria Barat. ${ }^{27} \mathrm{Hal}$ itu termasuk bersangkutan dengan pemberlakuan nilai-nilai Barat, nilai-nilai hak-hak asasi, di negara-negara lain. Masalahnya, di dalam diskursus nilai itu, orang cepat sekali lupa bahwa demokrasi dan hak-hak manusia itu lama diperjuangkan di Barat dan sering menimbulkan banyak korban, sebelum keduanya dijangkarkan dalam institusiinstitusi politis dan hukum masyarakat-masyarakat Barat. ${ }^{28}$ Dengan kata lain, ide tentang hak-hak asasi manusia bukanlah komponen kebudayaan-kebudayaan Barat yang tersedia begitu saja, melainkan merupakan hasil pengalaman-pengalaman negatif dari kesewenangan kekuasaan dalam tegangan-tegangan peradaban modern.

Masalahnya, Barat terlihat ingin memberlakukan ide hak-hak asasi manusia ini di tempattempat yang didominasikan oleh kesewenangan kekuasaan dan di tempat yang kondisi hidupnya buruk. Negara bekas koloni tersebut takut bahwa politik hak-hak asasi manusia itu akan tumbuh menjadi kelanjutan kekuasaan kolonial dengan sarana lain, yakni imperalisme

\footnotetext{
${ }^{25}$ F. Budi Hardiman. Hak-Hak Asasi Manusia, h. 104.

${ }^{26}$ F. Budi Hardiman. Hak-Hak Asasi Manusia, h. 104.

${ }^{27}$ F. Budi Hardiman. Hak-Hak Asasi Manusia, h. 105.

${ }^{28}$ F. Budi Hardiman. Hak-Hak Asasi Manusia, h. 105.
} 
budaya hukum. ${ }^{29}$ Untuk memungkinkan koeksistensi damai di antara bangsa-bangsa, harus ada sesuatu semacam konsensus minimal tentang cara-cara bergaul dalam dunia internasional yang memungkinkan bangsa-bangsa dari kebudayaan-kebudayaan yang berbeda-beda untuk saling mengerti. ${ }^{30}$ Penegasan diri negara-negara di Kawasan Asia Timur sekurang-kurangnya memberi sebuah petunjuk bahwa pergaulan di antara bangsa-bangsa tidak dapat distrukturisasi ataupun diatur melalui satu-satunya sudut pandang yaitu sudut pandang Barat. Berdasarkan analisis Budi Hardiman, para penulis Barat sendiri telah mencoba bersikap kritis terhadap kebudayaan mereka sendiri. ${ }^{31}$ Mereka bahkan menuntut masyarakat Barat sendiri untuk mengubah sikap terhadap kebudayaan-kebudayaan lain. Hal ini juga berkenaan dengan hak-hak asasi manusia di mana Barat juga dapat belajar dari gambaran-gambaran tentang manusia dan etika-etika kebudayaan-kebudayaan non-Barat. Sikap belajar tersebut tentu menuntut sebuah politik yang sesuai dan bersikap adil terhadap fakta pluralisme kultural. Fakta tersebut melihat adanya penegasan diri, etnis, religius, ras, linguistis, ataupun regional tidak sebagai arkhais atau bawahan, dan tidak sebagai irasionalitas yang harus ditindas atau diatasi, melainkan bergaul dengan mereka seperti juga dengan ketidaksamaan, penyalahgunaan kekuasaan dan berbagai masalah-masalah sosial lainnya.

Bagi Budi Hardiman, tuntutan-tuntutan untuk belajar dari kebudayaan-kebudayaan lain dan untuk mengatasi sikap etnosentris sendiri juga berlaku untuk kebudayaan-kebudayaan lain, termasuk kebudayaan Asia Timur. ${ }^{32}$ Kebudayaan-kebudayaan di Asia Timur tentu mengandung unsur-unsur yang mutlak untuk kehidupan bersama manusia. Mereka bukanlah kebudayaan-kebudayaan yang tidak ramah kepada manusia dan seharusnya juga tidak dinilai demikian. Hal ini dikarenakan adanya pemahaman bahwa kebudayaan manusia bukanlah sebuah fosil yang tidak dapat berubah ataupun harus dikonservasi. Kebudayaan berubah dan memperbarui dirinya melalui konfrontasi-konfrontasi dan perjumpaan-perjumpaan dengan kebudayaan-kebudayaan lain. Masalahnya adalah bagaimana melindungi nilai-nilai Asia dari pengaruh gaya hidup Barat tidaklah dapat dimutlakkan. Pertanyaan penting yang dapat kita gumulkan yaitu bagaimana intensi dasar hak-hak asasi manusia dapat dilakukan dalam horizon kebudayaan-kebudayaan Asia Timur? Orang Asia bagaimanapun melalui perjumpaan, kontak, dan bentrokan dengan kebudayaan Barat telah menerima gagasan modern tentang demokrasi dan negara hukum, termasuk upaya mempertahankan cara mereka sendiri untuk memahami hubungan antara hak-hak dan kewajiban-kewajiban.

\footnotetext{
${ }^{29}$ F. Budi Hardiman. Hak-Hak Asasi Manusia, h. 106.

${ }^{30}$ F. Budi Hardiman. Hak-Hak Asasi Manusia, h. 107.

${ }^{31}$ F. Budi Hardiman. Hak-Hak Asasi Manusia, h. 107.

${ }^{32}$ F. Budi Hardiman. Hak-Hak Asasi Manusia, h. 108.
} 
Tampaknya, kekhasan kebudayaan Asia demikian sering ditekankan sebagaimana terlihat dalam berbagai perdebatan mengenai nilai-nilai Asia. Oleh karenanya, muncullah kesan bahwa kebudayaan Asia lebih memprioritaskan kewajiban-kewajiban daripada hak-hak.

Budi Hardiman juga mengajak kita berpikir kritis bahwa pemahaman tentang hak-hak dan kewajiban-kewajiban di Asia tidaklah seragam. ${ }^{33}$ Hal itu juga termasuk adanya pemahaman kata "Asia" itu sendiri adalah ciptaan orang Barat yang sebenarnya telah mengecoh kita dengan homogenitas. Bagi Budi Hardiman, kata ini sebenarnya adalah sebuah abstraksi dan berfungsi sebagai semacam konsep super untuk banyak negara, bangsa, dan suku di bagian bumi ini. ${ }^{34}$ Sebagai contoh, orang Indonesia, Jepang, Korea, India, Singapura memiliki identitas-identitas kultural yang berbeda-beda. Di dalam masing-masing negara tersebut, kita dapat melihat adanya kompleksitas internal dan bukan keseragaman kebudayaan. Selain itu, jika kita mendefinisikan hak-hak personal sebagai tuntutan-tuntutan individu kepada masyarakat atau negara, kita tentu tidak akan menemukan hak-hak sedemikian rupa di kebudayaan Jawa. Sebab, konsep hak yang di Barat berkembang melalui Pencerahan, Revolusi Perancis, dan Revolusi Amerika, dan dimengerti sebagai hak-hak kebebasan subyektif atau hak-hak negatif yang melindungi berbagai ruang tindakan individu dan melarang intervensi terhadap kebebasan, hidup, dan milik individu.

Bila ditelusuri dalam politik dan kebudayaan, bukti yang paling jelas untuk acuan pada hak-hak tertentu dalam kebudayaan Asia adalah pemberontakan-pemberontakan petani atau gerakan Ratu Adil dari wong cilik di tanah Jawa. Bagaimana tidak, kolonialisme dan pengalaman negatif yang dihasilkan telah membangkitkan kesadaran hak-hak di Asia. Kenyataan bahwa wong cilik dalam berbagai dinamika keadaan ekstrim telah meninggalkan anonimitas mereka dan bangkit melawan raja, atasan, atau melawan orang Belanda yang telah menindas mereka. Mereka melakukannya karena mereka protes keras-keras melawan para penyebab pengalaman penderitaan mereka berupa kelaparan, penyakit, kemiskinan, penyiksaan, dan penindasan. Namun persoalannya adalah bagaimanakah orang-orang miskin, kaum tertindas, dan wong cilik dalam masyarakat Jawa itu memahami berbagai tuntutan dasariah yang Barat definisikan sebagai hak-hak? Budi Hardiman mengingatkan kita bahwa dalam tilikan politik, ada perbedaan mendasar antara pemahaman tentang hak di Barat dan di Jawa yang dapat diturunkan dari masing-masing kebudayaan. ${ }^{35}$ Misalnya, kebudayaan Jawa tidak memberi prioritas pada individu, melainkan komunitas dan kepentingan-kepentingan komunitas. Paradigma kebudayaan ini tentu berdampak pada

\footnotetext{
${ }^{33}$ F. Budi Hardiman. Hak-Hak Asasi Manusia, h. 112.

${ }^{34}$ F. Budi Hardiman. Hak-Hak Asasi Manusia, h. 112.

${ }^{35}$ F. Budi Hardiman. Hak-Hak Asasi Manusia, h. 122.
} 
gagasan tentang hak. Hak tidak dimengerti sebagai hak-hak individu yang diklaim di hadapan kelompok. Klaim-klaim atas hak-hak itu diajukan selalu hanya dalam kerangka komunitas dan kepentingan komunitas itu. Dengan kata lain, hak dimengerti secara solidaritas.

Lalu, bagaimana hubungan antara hak dan kewajiban? Dalam konteks kebudayaan Jawa, kita dapat memahami bahwa Jawa memang cenderung memprioritaskan kewajiban di atas hak, tetapi klaim-klaim atas hak tidak pernah sirna kendati adanya tuntutan yang kuat dari kewajiban-kewajiban. ${ }^{36}$ Namun jika terbukti adanya suatu tatanan yang tidak adil atau korup dalam kenyataan sosial, kewajiban-kewajiban sosiokultural seperti tuntutan untuk rukun dapat direlatifkan oleh hak-hak yang dipahami secara solidaritas itu. Masalahnya, keadaan demikian hanya terjadi di masa darurat saja. Apabila penguasa telah berhasil menstabilkan kembali masyarakat, maka akan masih ada bahaya bahwa mereka menggunakan pemahaman diri kultural yang memprioritaskan komunitas dan ototitas ini sebagai alat ideologis untuk melanggengkan dominasi mereka. Gagasan ini dapat kita temukan dalam perjalanan sejarah Suharto.

\section{Penutup}

Dalam tilikan politik, kita tidak boleh lupa bahwa hak asasi manusia harus dipahami sebagai kebebasan untuk bertindak tanpa pembatasan. Hal ini tentu bermakna bahwa seolaholah pelaksanaan hak-hak tersebut tidak mensyaratkan pengujian etis dan tanggung jawab sehingga dibutuhkan gagasan tentang kewajiban. Bila diteliti, pemikiran ini tentu tidak sesuai dengan apa yang menjadi intensi deklarasi hak-hak asasi manusia. Dalam hal ini, kebebasan bukanlah dipahami sebagai pemakaian kesewenangan, melainkan ditafsirkan dalam horizon keutamaan dan kesejahteraan umum. ${ }^{37}$ Kalau demikian, tanggung jawab manusia sudah tersirat di dalam hak-hak asasi manusia. Walaupun, kita juga tidak boleh lupa bahwa deklarasi hak asasi manusia merupakan sebuah jawaban atas pengalaman-pengalaman ekstrim penderitaan dan ketidakadilan. Di sisi lain, kita juga dapat memahami bahwa orang baru dapat menuntut pelaksanaan hak, jika orang telah memenuhi kewajiban-kewajiban yang sesuai dengannya. Bila diteliti, gagasan ini mengandung adanya bahaya relativasi hak asasi manusia sebagai hak yang tidak dapat diasingkan yakni sebagai hak yang sudah ada secara alamiah tanpa mengandaikan suatu prestasi apapun.

\footnotetext{
${ }^{36}$ F. Budi Hardiman. Hak-Hak Asasi Manusia, h. 123.

${ }^{37}$ F. Budi Hardiman. Hak-Hak Asasi Manusia, h. 125.
} 


\section{Daftar Pustaka}

Brysk, Alison dan Gershon Shafir (ed.). People Out of Place: Globalization, Human Rights, and Citizenship Gap. (New York \& London: Routledge, 2004

Evans, Tony. The Politics of Human Rights: A Global Perspective. London: Pluto Press, 2001.

Fakih, Mansour. Runtuhnya Teori Pembangunan dan Globalisasi. Yogyakarta: Pustaka Pelajar, 2001.

Hardiman, F. Budi. Hak-Hak Asasi Manusia: Polemik dengan Agama dan Kebudayaan. Yogyakarta: Kanisius, 2011.

Magnis-Suseno, Franz. Etika Politik: Prinsip Moral Dasar Kenegaraan Modern.Jakarta: Gramedia, 2016.

Santoro, Michael A. "Post-Westphalia and Its Discontents: Business, Globalization, and Human Rights in Political and Moral Perspective" dalam Business Ethics Quarterly 20: 2 (April 2010).

Soysa, Indra de dan Krishna Chaitanya Vadlamannati. "Does Being Bound Together Suffocate or Liberate? The Effect of Economic, Social, and Political Globalization on Human Rights, 1981-2005" dalam Kyklos Vol. 64 Februari 2011 No. 1 